\title{
Evaluation of Selected Species of Fodder Trees Cultivated for Feeding Ruminant Animals in the Hills of Nepal
}

\author{
Ramesh C. Khanal ${ }^{1}$ and Chet R. Upreti ${ }^{2}$ \\ ${ }^{1}$ Animal Nutrition Division, Nepal Agriculture Research Council, Khumaltar \\ ${ }^{2}$ Agricultural Research Station (Goat), Bandipur, Tanahun
}

\begin{abstract}
Leaves and twigs from four species of tree fodders, Aetocarpus lakoocha (AL), bauhinia purpurea (BP), Garuga pinnata (GP) and Ficus sroxburghii (FR), cultivated widely for feeding ruminants in the hills of Nepal and maintained at the Agriculture Research Station (Goat), Bandipur were investigated for there chemical composition, and nutrient intake, digestibility, and growth rate in growing female goats. Differences occurred between species of tree fodders on nutrient composition, which contained 286, 342, 312, and $263 \mathrm{~g} / \mathrm{kg} \mathrm{DM}$; $174,98,116$ and $178 \mathrm{~g} / \mathrm{kg}$ total ash; $137,163,140$, and $119 \mathrm{~g} / \mathrm{kg} \mathrm{CP} ; 440,458,437$, and 451 $\mathrm{g} / \mathrm{kg} \mathrm{NDF} ; 383,407,382$, and $406 \mathrm{~g} / \mathrm{kg}$ ADF; 177, 135, 181, and $143 \mathrm{~g} / \mathrm{kg} \mathrm{ADL} ; 19.5,21.6$, 20.9 , and $29.3 \mathrm{~g} / \mathrm{kg} \mathrm{Ca}$; and 2.2, 2.8, 2.4, and $2.5 \mathrm{~g} / \mathrm{kg} \mathrm{P}$ on DM basis for AL, BP, GP, and FR, respectively. The DM intake was higher for goats fed AL (432 g/d) and GP (428 g/d) than BP $(342 \mathrm{~g} / \mathrm{d})$ or FR $(306 \mathrm{~g} / \mathrm{d})$. Nutrient digestibility was higher for goats fed AL and $\mathrm{GP}$, except $\mathrm{Ca}$, which was higher for goats fed FR. Similarly, highest daily weight gain was observed for goats fed AL $(71 \mathrm{~g} / \mathrm{d})$ and GP $(64 \mathrm{~g} / \mathrm{d})$ than either of BP $(54 \mathrm{~g} / \mathrm{d})$ or FR (30 $\mathrm{g} / \mathrm{d}$ ). Overall, leaves and twigs from these tree fodders supported moderate growth, but may not be advisable for maximum production.
\end{abstract}

Key words: Digestibility, goat, nutritive value, performance, tree fodders

\section{INTRODUCTION}

Fodder trees are grown in the hills of Nepal from the immemorial. Their importance in supplying fodder, fuel wood, protection of soil erosion and environment, and some other household needs has been well documented (Pandey 1982). Inadequate feed supply and poor nutrition during the dry winder and early summer season (mid-January through mid-May) are the major constraints to increase ruminant production in the hill of Nepal (Kiff et al 1999). Of the 75 administrative districts in the country, 50 were found to be less than $80 \%$ sufficient in supplies of livestock feed (Schreier et al 1991). Leaves and twigs collected from several species of fodder trees cultivated in a great variety of soil and climatic condition are a main source of green forage for ruminants during dry winter and early month and help maintain the body condition and production of ruminants.

Khanal and Subba (2001) described the nutritional characteristics of leaves and twigs from 31 species of fodders trees cultivated in the hill of Nepal. Khanal et al (1999) have determine the proximate composition, detergent fibers, and $\mathrm{Ca}$ and $\mathrm{P}$ contents of both cultivated and uncultivated tree fodders and browse plants available mostly in the western hill of Nepal. Similarly, Subba (1998)

has determined the detail chemical composition of leaves from those available in eastern hills of Nepal. Subba (1999) also ranked them according to various nutritional characteristics. On the other hand farmers have their own preference based on there age-old practices in the cultivation and feeding of leaves and twigs from various species of tree fodders. Realizing this, Thorne et al (1999) and Walker et al (1999) attempted to derive a biological interpretation of indigenous knowledge system with regard to the quality of tree fodders and consistency and discriminatory power of indigenous and laboratory assessment of the nutritive values of tree fodders available in Nepal. Thorne et al (1999) also attempted to find the potential complementarities between indigenous and laboratory-based indicators of tree fodder quality. However, part of there interpretation was based not on actual animal performance, but on in vitro studies. As a result, several of these authors pointed out the need to investigate on the quality of various fodder trees and shrubs based on the 
actual performance of ruminants. This would ultimately help reduce the severity of scarcity of feed and fodder and maintain ruminant production. Therefore, objective of this study was to investigate the performance of goats upon feeding leaves and twigs from four species of selected fodder trees commonly cultivated in the hills of Nepal.

\section{MATERIALS AND METHODS}

Sixteen female growing Khari goats with an average initial weight of $8.89 \pm 0.6 \mathrm{~kg}$ and age of $140 \pm$ 20 days were selected for the study. Animals were blocked according to there initial body weight. Within block animals were allotted at random to one of four treatments, ie species of tree fodders selected for the study. Tree fodder species were Badahar (Artocarpus lakoocha; AL), Tanki (Bauhinia purpurea; BP), Dabdabe (Garuga pinnata; GP) and Nemaro (Ficus roxburghii; FR), selection of which was based on their widespread availability across the low and mid hills of Nepal. While AL is regarded as the one of the most nutritious fodder tree species by the farmers, BP is a leguminous fodder and expected to have higher protein contents. The GP is a relatively large with small thin leaves, whereas FR has big, rounded, and thick leaves with a relatively large mid-rib. Leaves and twigs from the fodder trees were collected from the same north facing fodder block maintained in Agriculture Research Station (ARS, Goat), Bandipur at an altitude of $875 \mathrm{~m}$ from the sea level. Soil had a pH of 5.64 with $3.2 \%$ organic carbon, $174.3 \mathrm{ppm}$ of available phosphorus, and $0.27 \%$ total nitrogen. The station received an annual rainfall of $2000 \mathrm{~mm}$ with an average of $85 \%$ relative humidity, and minimum and maximum temperature of 8 and $32^{\circ} \mathrm{C}$, respectively.

Experimental goats were housed in individual cages in the same shade with facilities for collection of feed, orts and feces, but not urine. Goats were allowed to have an ad Libitum access to leaves and twigs from one of the four fodder trees mentioned above. Water was offered twice daily at $1000 \mathrm{~h}$ and $1700 \mathrm{~h}$ while tree fodder leaves together with twigs and petioles were offered twice daily at $0900 \mathrm{~h}$ and $1600 \mathrm{~h}$. Orts were collected $2 \mathrm{~h}$ after feeding. All animal were de-wormed before allotting them to the experiment and further medication, if any, was administered as per the suggestion of a veterinarian.

Total experimental period was 74 days including a 14-day adaptation period, which was conducted during Feb-May 2000. Growth was monitored every fortnight. Feed offered and orts were collected daily for determining the daily feed and nutrient intakes. Total fecal output was measured during the final 8 days of the experiment and their samples collected during the total collection period. Dry matter (DM) content of the feeds offered and orts collected as well as fecal samples was determined daily during the last 8 days of digestibility study.

Laboratory analyses of the tree fodder leaves and twigs offered and fecal samples collected was done for DM, crude protein (CP) and total ash (TA), contents as per AOAC (1980). Neutral detergent and acid detergent fiber (NDF and ADF) as well as acid detergent lignin (ADL) were determined as per (Van Soest and Robertson 1985). Samples of leaves and twigs were analyzed for their chemical composition every fortnight during the experiment. These samples were air dried at ARS (Goat), brought to Animal Nutrition Division Laboratory, and ground to pass through a 1-mm sieve for further laboratory analyses. Wherever appropriate, all values are expressed on DM basis.

Data were statistically analyzed in SAS using PROC GLM (SAS 1999). Model included treatment and block as the independent variables. In case of final body weight, initial body weight was used as the covariate. Means were separated using REGWQ.

\section{RESULTS AND DISCUSSION}

Nutrient composition of the leaves and twigs from selected species of fodders trees is given in Table 1. The DM content was higher for $\mathrm{BP}(\mathrm{P}<0.05)$ than $\mathrm{AL}$ and $\mathrm{FR}$, but there was no difference $(\mathrm{P}>$ $0.05)$ between the other species of tree fodders. The values were comparable to the earlier reports for the same species of tree fodder harvested at similar times of the year (Khanal and Subba 2001, 
Throne et al 1999, Wood et al 1994). The DM content would increase with the increasing maturity, which was probably another reason why it is higher for BP that was approaching fruit bearing stage. Crude protein content varied significantly $(\mathrm{P}<0.05)$ among species, highest being for $\mathrm{BP}$, which is a leguminous tree fodder. Crude protein content in all of them was slightly lower than reported previously (Khanal and Subba 2001, Khanal et al 1999, Subba 1998). It was probably because of the difference in sampling procedures employed between the studies. While leaves and twigs were included in the current study to represent the actual feeding practices of the farmers, it was only the leaves that were used to determine CP content previously (Khanal and Subba 2001). Time of harvest also affect the CP content with the same species of tree fodder varying in CP content by about 30 to $40 \%$ when harvested at different times of the year (Topps 1992, Wood et al 1994). Nonetheless, all of them could be regarded to have medium CP content, which could make a valuable source of protein for ruminants. Moreover, Subba (1999) has shown that a higher proportion of CP present in this tree fodders is actually present in the form available to ruminants. The ash content was also different $(\mathrm{P}<0.05)$ among the four species of tree fodders with smaller values for BP and GP than either of the AL or FR. While Wood et al (1994) reported higher ash contents for AL and FR, Khanal and Subba (2001) reported slightly lower ash content for BP and GP. Such variations may exist owing to the difference in harvesting season, fodder maturity, leaf : twig ratio and even soil condition and topography.

Table 1. Nutrient composition (g/kg) of leaves and twigs from selected species of fodder trees ${ }^{1}$ used for feeding ruminant in the hills of Nepal

\begin{tabular}{lrrrrr}
\hline Nutrient & \multicolumn{3}{c}{ Fodder tree species } & SEM $^{2}$ \\
\cline { 2 - 5 } & AL & BP & GP & FR & \\
\hline DM & $286^{\mathrm{b}}$ & $342^{\mathrm{a}}$ & $312^{\mathrm{ab}}$ & $263^{\mathrm{b}}$ & 17.4 \\
Total ash & $174^{\mathrm{a}}$ & $98.2^{\mathrm{b}}$ & $116^{\mathrm{b}}$ & $178^{\mathrm{a}}$ & 13.5 \\
CP & $137^{\mathrm{bc}}$ & $163^{\mathrm{a}}$ & $140^{\mathrm{ab}}$ & $119 \mathrm{c}$ & 9.3 \\
NDF & 440 & 458 & 437 & 451 & 27.1 \\
ADF & 383 & 407 & 382 & 406 & 35.0 \\
ADL & 177 & 135 & 181 & 143 & 32.1 \\
Ca & 19.5 & 21.6 & 20.9 & 28.3 & 3.2 \\
P & 2.2 & 2.8 & 2.4 & 2.5 & 0.5 \\
\hline
\end{tabular}

Figure in the same row with different superscripts differs $(P<0.05) .{ }^{1}$ Fodder tree species used were $A L$, Artocarpus lakoocha. BP, Bauhinia purpurea. GP, Garuga pinnata, FR, Ficus roxburgii. ${ }^{2}$ Standard error of mean.

No significant difference $(\mathrm{P}>0.05)$ in detergent fibers or $\mathrm{Ca}$ and $\mathrm{P}$ content was observed among species. The NDF content was lower than previous reports for AL and BP, but it was similar in case of GP and FR (Khanal and Subba 2001). Thorne et al (1999) reported higher NDF and ADF values for FR than was observed in the current study. AS expected, ADL content was high for all species. Relatively higher ADL and lower hemicellulose content (NDF minus ADF) is probably one of the characteristics of tree fodder and shrubs fed to ruminants. Similar results of high ADL and LOW hemicellulose content have been reported previously for these tree fodders cultivated under similar condition (Subba 1998). Calcium content was close to or more than $2 \%$ on DM basis. High Ca and medium to high CP content is worth considering, because hill farmers of Nepal give a priority to feed tree fodder leaves and twigs to lactating ruminants, primarily buffaloes that have greater demand for $\mathrm{CP}$ and $\mathrm{Ca}$ contents during early lactation. This may also be useful while making feeding packing and supplementation strategies for ruminant production in the hills of Nepal, particularly during drier months. The $\mathrm{P}$ content was within the normal range of requirement in the forages (McDowell 1997).

There was a significant difference $(\mathrm{P}<0.05)$ in the nutrient intake of animals (Table 2), lowest nutrient intakes being for FR group. The DMI, DMI $/ 100 \mathrm{~kg}$ bwt and DMI $/ \mathrm{kg} \mathrm{w}^{0.75}$ was lower for BP and FR group than AL and GP groups. Large thick leaves and twig like mid rib in case of FR and thinly distributed leaves that would increase the overall proportion of twigs in case of BP might have contributed to the lower DM intakes. It was observed during the experiment that goats did not relish FR and had palatability problems. Aryal et al (1994) have observed higher intakes of DM with 620 $\mathrm{g} / \mathrm{d}$ when male goats weighing $7.6 \mathrm{~kg}$ initially were given various tree fodders (depending on the 
availability round the year) percent supplemented with concentrate $(16 \% \mathrm{CP})$ at $1 \%$ of their body weight. They have observed an intake of $3.8 \mathrm{~kg} \mathrm{DM} / 100 \mathrm{~kg} \mathrm{BW}$ and $76.2 \mathrm{~g} / \mathrm{kg} \mathrm{w}^{0.75}$, which was similar to that of AL and GP groups but higher than BP and FR groups. However, higher CP content (Table 1) led the similar $\mathrm{CP}$ intake in BP group compared with AL and GP groups. Other studies related to nutrient intakes of female goats fed such tree fodder leaves and twigs exclusively are limited. A dramatic increase in feed intake (and feed conversion ratio) in both sheep and goats have been observed when the basal diet was supplemented with rumen undegradable protein and starch (Throckmorton and Leng 1984). Since rumen undegradable protein and starch was not supplemented in the current study, their positive effects on intake and digestibility of nutrients could not be ascertained.

Table 2. Nutrient intake (g/kg) by female goats fed leaves and twigs from selected species of fodder trees ${ }^{1}$ used for feeding ruminant in the hills of Nepal

\begin{tabular}{lrrrrr}
\hline Nutrient & \multicolumn{4}{c}{ Fodder tree species } & SEM $^{2}$ \\
\cline { 2 - 5 } & AL & BP & GP & FR & 9.98 \\
\hline DM & $431.8^{\mathrm{a}}$ & $341.7^{\mathrm{b}}$ & $427.9^{\mathrm{a}}$ & $305.8^{\mathrm{c}}$ & 0.09 \\
$\mathrm{DM}, \% \mathrm{BW}$ & $3.95^{\mathrm{a}}$ & $3.27^{\mathrm{b}}$ & $3.98^{\mathrm{b}}$ & $3.14^{\mathrm{a}}$ & 1.69 \\
$\mathrm{DM}, / \mathrm{kg} \mathrm{w}^{0.75}$ & $72.0^{\mathrm{a}}$ & $59.0^{\mathrm{b}}$ & $72.2^{\mathrm{a}}$ & $55.5^{\mathrm{b}}$ & 7.38 \\
OM & $356.8^{\mathrm{b}}$ & $306.3^{\mathrm{c}}$ & $378.2^{\mathrm{a}}$ & $251.3^{\mathrm{d}}$ & 1.71 \\
Total ash & $75.0^{\mathrm{a}}$ & $35.3^{\mathrm{d}}$ & $48.7^{\mathrm{c}}$ & $54.5^{\mathrm{b}}$ & 1.54 \\
$\mathrm{CP}$ & $50.5^{\mathrm{b}}$ & $52.4^{\mathrm{ab}}$ & $55.8^{\mathrm{a}}$ & $30.3^{\mathrm{c}}$ & 0.17 \\
$\mathrm{Ca}$ & $8.42^{\mathrm{b}}$ & $5.82^{\mathrm{c}}$ & $8.94^{\mathrm{a}}$ & $8.96^{\mathrm{a}}$ & 0.03 \\
$\mathrm{P}$ & $0.95^{\mathrm{a}}$ & $0.96^{\mathrm{a}}$ & $1.03^{\mathrm{a}}$ & $0.76^{\mathrm{b}}$ & 0.03 \\
\hline
\end{tabular}

Figure in the same row with different superscripts differs $(P<0.05) .{ }^{1}$ Fodder tree species used were $A L$, Artocarpus lakoocha. BP, Bauhinia purpurea. GP, Garuga pinnata, FR, Ficus roxburgii. ${ }^{2}$ Standard error of mean.

Digestibility of nutrients was affected by the species of tree fodder and could be considered relatively low (Table 3). Inclusion of twigs with leaves may have contributed to the lower digestibility of nutrients. Higher ADL contents (Table 1) may also have rendered relatively poor digestibility of nutrients from these tree fodders since it forms complexes with hemicellulose, which would otherwise be digestible. Previous studies on tree fodder leaves have shown higher neutral cellulose, DM, and OM digestibility (Khanal and Subba 2001). Presence of antinutrient factors such as tannins may also have contributed to poor digestibility, because all but BP are shown to contain $>2 \%$ tannin in there leaves (Khanal and Subba 2001, Subba 1998, Wood et al 1994). Though not measured, tannin content in the current study might have been higher because of the inclusion of twigs. Digestibility of nutrients for AL and GP was similar and significantly higher $(\mathrm{P}<0.05)$ than that of BP and FR, which were not different $(\mathrm{P}>0.05)$ from each other in most of the cases, except digestibility of total ash and $\mathrm{Ca}$. However, Ca digestibility was highest $(\mathrm{P}<0.01)$ for FR than for the rest, reasons for which were not clear.

Daily weight gain, feed: gain ratio, and final body weight of female goats are given in Table 4 while the growth pattern every fortnight is presented in Figure 1 and 2. Higher nutrient intake accompanied by better digestibility of various nutrients might have had positive effect on the significantly $(\mathrm{P}<0.05)$ better growth rates of female goats fed AL and GP than BP or FR. Goats in AL group tended to grow faster $(\mathrm{P}=0.08)$ than goats in GP group even though the digestibility and intakes of nutrients in these two groups were similar. Farmers, however, consider AL as the most Posilo (nutritious) tree fodder, regard it as the king of tree fodders, and often feed it to lactating buffaloes only. Two of the four animals fed FR lost their body weight during the $2^{\text {nd }}$ and $3^{\text {rd }}$ fortnights of the experiment. This must be due to poor intake and digestibility of the fodder species concerned, which was probably not sufficient to meet the maintenance requirement of the animals. Growth rate of other groups of animal was also relatively poor, because high growth rates cannot be supported to the products of fermentative digestion and that rumen undegradable protein supplements are essential to take advantage of the energy absorbed from volatile fatty acids (Preston 1998). Another reason may be the sex of the animals since females grow at slower rates than males at similar age (Anous and Mourad 1993). 
Table 3. Nutrient digestability (\%) by female goats fed leaves and twigs from selected species of fodder trees ${ }^{1}$ used for feeding ruminant in the hills of Nepal

\begin{tabular}{|c|c|c|c|c|c|}
\hline \multirow[t]{2}{*}{ Nutrient } & \multicolumn{4}{|c|}{ Fodder tree species } & \multirow[t]{2}{*}{$\mathrm{SEM}^{2}$} \\
\hline & AL & $\mathrm{BP}$ & GP & FR & \\
\hline DM & $53.4^{\mathrm{a}}$ & $46.5^{\mathrm{ab}}$ & $58.8^{\mathrm{a}}$ & $44.8^{\mathrm{b}}$ & 3.02 \\
\hline $\mathrm{OM}$ & $58.9^{\mathrm{a}}$ & $46.1^{\mathrm{b}}$ & $65.5^{\mathrm{a}}$ & $46.0^{\mathrm{b}}$ & 3.73 \\
\hline Total ash & $58.4^{\mathrm{a}}$ & $49.3^{b}$ & $47.0^{\mathrm{b}}$ & $34.5^{\mathrm{c}}$ & 3.89 \\
\hline $\mathrm{CP}$ & $53.2^{\mathrm{a}}$ & $45.0^{\mathrm{b}}$ & $57.0^{\mathrm{a}}$ & $44.1^{\mathrm{b}}$ & 2.26 \\
\hline NDF & $50.3^{b}$ & $40.8^{\mathrm{a}}$ & $50.3^{\mathrm{a}}$ & $42.5^{b}$ & 2.32 \\
\hline $\mathrm{ADF}$ & $45.2^{\mathrm{a}}$ & $40.2^{\mathrm{ab}}$ & $49.4^{\mathrm{a}}$ & $38.7^{\mathrm{b}}$ & 3.50 \\
\hline Hemicellulose & $49.3^{b}$ & $38.2^{\mathrm{c}}$ & $60.4^{\mathrm{a}}$ & $41.0^{c}$ & 2.06 \\
\hline $\mathrm{Ca}$ & $60.7^{\mathrm{ab}}$ & $47.7^{\mathrm{c}}$ & $55.5^{\mathrm{b}}$ & $65.7^{\mathrm{a}}$ & 1.88 \\
\hline $\mathrm{P}$ & $47.9^{\mathrm{ab}}$ & $38.1^{\mathrm{c}}$ & $50.7^{\mathrm{a}}$ & $41.6^{\mathrm{bc}}$ & 2.62 \\
\hline
\end{tabular}

Figure in the same row with different superscripts differs $(P<0.05) .{ }^{1}$ Fodder tree species used were $A L$, Artocarpus lakoocha. BP, Bauhinia purpurea. GP, Garuga pinnata. FR, Ficus roxburgii. ${ }^{2}$ Standard error of mean.

Table 4. Final body weight, average daily gain, and feed gain ratio of female goats fed leaves and twigs from selected species of fodder trees ${ }^{1}$ cultivated in the hills of Nepal

\begin{tabular}{|c|c|c|c|c|c|}
\hline \multirow[t]{2}{*}{ Nutrient } & \multicolumn{4}{|c|}{ Fodder tree species } & \multirow[b]{2}{*}{ SEM $^{2}$} \\
\hline & $\mathrm{AL}$ & $\mathrm{BP}$ & GP & FR & \\
\hline Final BW, kg & $13.0 \mathrm{a}$ & $12.1 \mathrm{~b}$ & $12.7 \mathrm{ab}$ & $10.6 \mathrm{c}$ & 0.31 \\
\hline Daily gain, $g / d$ & $71.1 \mathrm{a}$ & $53.9 b$ & $64.4 \mathrm{a}$ & $29.7 \mathrm{c}$ & 3.24 \\
\hline Feed:gain ratio & $6.07 \mathrm{a}$ & $6.34 \mathrm{a}$ & $6.64 a$ & $10.3 b$ & 0.87 \\
\hline
\end{tabular}

Figure in the same row with different superscripts differs $(\mathrm{P}<0.05) .{ }^{1}$ Fodder tree species used were AL, Artocarpus lakoocha. BP, Bauhinia purpurea. GP, Garuga pinnata. FR, Ficus roxburgii. ${ }^{2}$ Standard error of mean.

An overall weight gain of $81 \mathrm{~g} / \mathrm{d}$ was obtained under Indian conditions when Sirohi, Marwari and Kutchi goats were raised between 3 to 6 months of age (Nagpal et al 1995), all of which are heavier breeds than Khari used in the current study. A maximum growth of $66 \mathrm{~g} / \mathrm{d}$ was observed between 6 to 12 months of age in Nepali hill bucks (Khari) in eastern Nepal when goats were allowed to have ad libitum access to tree fodders and supplemented with corn at $25 \mathrm{~g} / \mathrm{d}$ per bwt (Shrestha et al 1990). However, the growth declined to $48 \mathrm{~g} / \mathrm{d}$ when supplemental corn was reduce to $10 \mathrm{~g} / \mathrm{d}$ per $\mathrm{kg}$ body weight. Growth rate was even less at $41.3 \mathrm{~g} / \mathrm{d}$ per $\mathrm{kg}$ bw for male kids that weighed $7.6 \mathrm{~kg}$ initially and reared for one year on ad libitum access to tree fodders supplemented with concentrate at $1 \%$ of there body weight (Aryal et al 1994). Although daily weight gain obtained in the current study was better than or comparable tot hat observed previously in the same breed (Upreti et al 1999, Upreti and Khanal 1998) Aryal et al 1994, Shrestha et al 1990), it was poorer than many other international findings (Penning et al 1996, Mahgoub and Lodge 1996, Nagpal et al 1995). Supplementation of rumen undegradable protein would probably have increased their growth rate.

Weight gain was highest during the first fortnight of the experiment and significant difference $(\mathrm{P}<$ 0.01 ) existed in the growth rates during all stages of growth, from the beginning to the end of the experiment. Consistent with the daily gain, final weight was also higher for goat fed AL and GP than BP or FR. Final weight at 6 month of age in the current study was similar to that observed previously at the same age of the same breed maintained at Lumle Farm in the western hills of Nepal (Khanal et al 2005). Lower final weight and poor growth rate led to poorer feed: gain ratio for goat fed FR than goats fed the rest of fodders. Overall the growth rate was poor for goats irrespective of the species of tree fodder and raising goats solely on such fodder and raising goats slowly on such fodder tree leaves and twigs may not advisable for optimum production. 


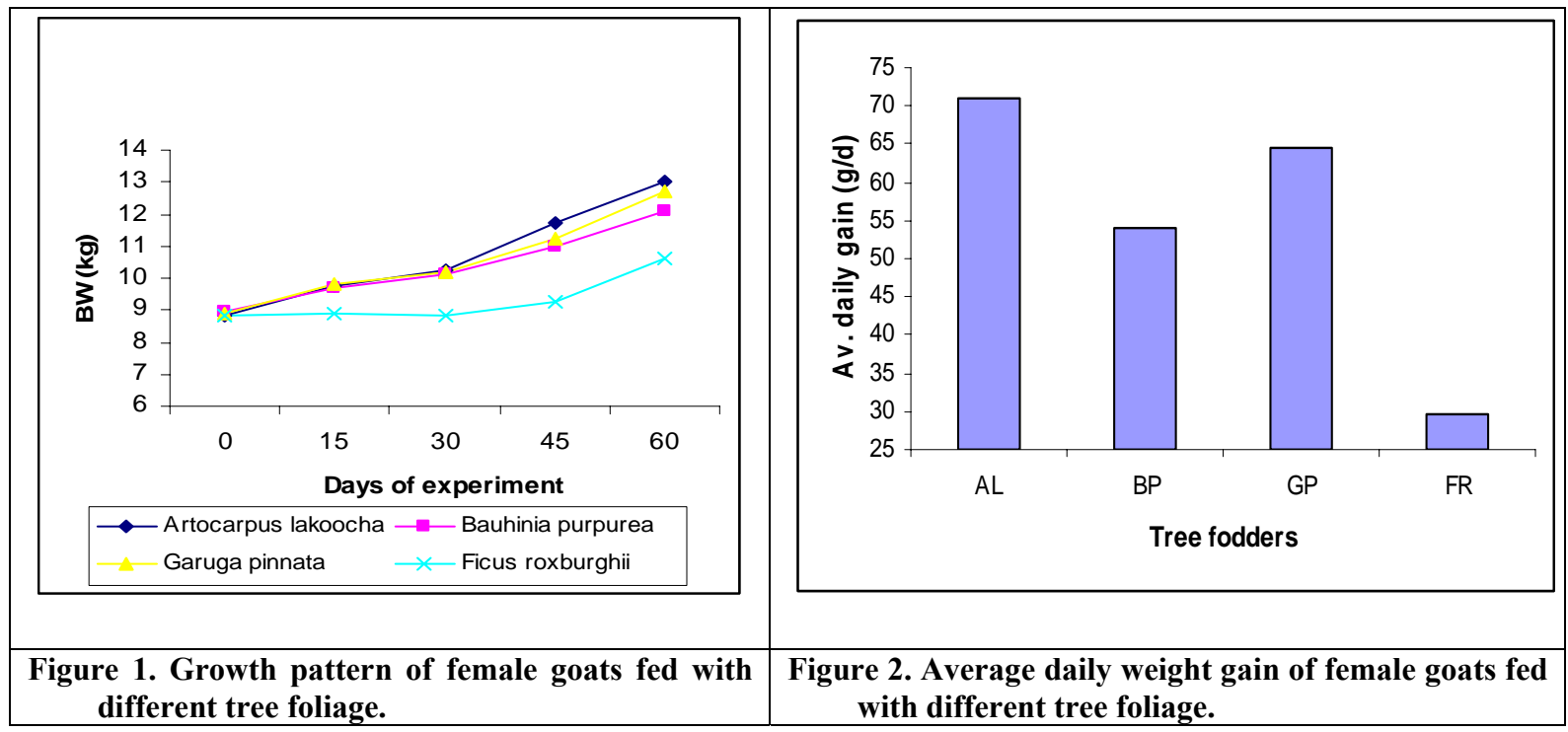

\section{CONCLUSIONS}

Feeding of leaves and twigs from different species of fodder tree to growing female goats showed the difference existed not only in the nutrient composition among individual fodder trees species, but also in the intake, digestibility and performance of the animals. Artocarpus lakoocha and Garuga pinnata were better in terms of overall response by the animals. Bauhinia purpurea, though highest in crude protein content, was not as good as Artocarpus lakoocha and Garuga pinnata in terms of animal performance. Ficus ruxburghii was merely able to maintain the animals. Based on the performances of female goats in the current study, feeding of these species of tree fodder is probably not sufficient to sustain higher production from ruminants. Further studies on the effects of supplementing this vital source of fodder with rumen undegradable protein, starch or both on nutrient intake, digestibility, and performance of the animal is important.

\section{ACKNOWLEDGMENTS}

We acknowledge Nepal Agriculture Research Council for making research fund available, DK Dewan and KB Neupane for lab works and MP Saha for care and management of experimental animals. A critical comment made by Dr BR Joshi is highly appreciated.

\section{REFERENCES}

Anous MR and MM Mourad. 1993. Cross breeding effect on reproductive traits of kids. Small Rumin. Res. 12:141-149.

AOAC. 1980. Official methods of analysis. $13^{\text {th }}$ Edition. Association of Official Analytical Chemists, Washing DC.

Aryal RC, NP Shrestha, SP Neopane, HB Gurung and AR Gurung. 1994. Effect of feeding Banmara (Eupatarium adenophorum) on fattening goats. PAC Technical Paper No. 158. Pakhribas Agricultural Center, Dhankuta, Nepal.

Khanal RC and DB Subba. 2001. Nutritional evaluation of leaves from some major fodder trees cultivated in the hills of Nepal. Animal Feed Science Technology 92:17-32.

Khanal RC, DP Rasali, TS Dhaubhadel, BR Joshi and NPS Karki. 2005. Comparative performance of indigenous Khanri and Kahri * Sinhal goats at Lumle farm. Nepal. J. Biol. Sci. 5:124-128.

Khanal RC, SB Panday and SK Khanal. 1999. Nutrient content in the fodder trees and shrubs found in various parts of Nepal. Paper presented in the $1^{\text {st }}$ Convention of the Society of Agriculture Scientists/Nepal, 9-11 June, Kathmandu. 
Kiff E, P Thorne, BH Pandit, D Thomas and SM Amatya. 1999. Livestock production systems and the development of fodder resources for the mid hills of Nepal. Department of Forestry Research and Survey, Natural Resources Institute and Nepal Agroforestry Foundation. 78 p.

Mahgoub O and GA Lodge. 1996. Growth and body composition in meat production of Omani Batina goast. Small Ruminant Res. 19:233-236.

McDowell LR. 1997. Minerals for grazing ruminants in tropical regions. University of Florida, Institute for food and Agriculture Science in USA.

Nagpal AK, VSP Singh and PC Jain. 1995. Effect of weaning age and feeding system on growth performance and carcass traits of male kide in three breeds in India. Small Rumin. Res. 17:4550.

Pandey KK. 1982. Fodder trees and tree fodder in Nepal. Swiss Development Cooperation. Berne, Switzerland.

Penning PO, RH Johnson and RJ Orr. 1996. Effect of continuous stocking with ship or goats on sward composition and animal production from a grass and white clover pasture. Small Rumin. Res. 21:19-29.

Preston TR. 1998. Tropical animal feeding: A manual for research workers. FAO Animal Production and Health paper No. 126. Food and Agriculture Organization of the United Nations, Rome.

SAS. 1999. SAS user's guide. Release 8.2. SAS Inst., Cary, NC.

Schreier H, S Brown, G Kennedy and PB Shah. 1991. Food, feed and fuel wood resources of Nepal: A GIS evaluation. Environment Management 15:815-822.

Shrestha NP, SP Neopane and HB Gurung. 1990. Effect of athelminthic treatment and feeding regimes on growth rate of local goats. PAC Technical Paper No. 127. Pakhribas Agricultural Center, Dhankuta, Nepal.

Subba DB, 1999. Tree fodder and browse plant as potential nutrition suppliers for ruminants. In: Proc. $3^{\text {rd }}$ Natl. Workshop Lives. Fisheries Res. Nepal (RC Khanal and SP Neopane, eds). National Animal Science Research Institute, Nepal Agricultural Research Council (NARC), Khumalter, Lalitpur, Nepal. Pp. 1-14.

Subba DB. 1998. Chemical composition and nutritive value of feed of East Nepal. Pakhribas Agricultural Center, Dhankuta, Nepal.

Thorne P, DB Subba, DH Walker, B Thapa, CD Wood, FL Sinclair. 1999. The basis of indigenous knowledge of tree fodder quality and its implications for improving the use of tree fodder in developing countries. Animal Feed Science Technology 81:119-131.

Throckmorton JC and RA Leng. 1984. Effect of bypass protein and bypass starch on milk yield and bodyweight gain in dairy cows. Animal Production Aust. 15:628-630.

Topps JH. 1992. Potential, composition and use of legume shrubs and trees as fodders for livestock in the tropics: Review. J. Agriculture Science 118:1-8.

Upreti CR and RR Khanal. 1998. Study on kids rearing - Effect of weaning of day on the growth performance of kids. Annual report - 1997/98. Agriculture Research Station (Goat) Bandipur, Tanahun, Nepal.

Upreti CR, SB Panday and MS Sapkota. 1999. Study on the effect of rice straw, tree leaves and concentrate feeding on goats. Annual report - 1998/99. Agriculture Research Station (Goat), Bandipur, Tanahun, Nepal.

Van Soest PJ and JB Robertson. 1985. Analysis of forages and fibrous foods: A laboratory manual for animal science 613. Cornell University, Ithaca, USA.

Walker DH, PJ Thorne, FL Sinclair, B Thapa, CD Wood and DB Subba. 1999. A systems approach to comparing indigenous and scientific knowledge: Consistency and discriminatory power of indigenous and laboratory assessment of the nutritive value of tree fodder. Agriculture System 62:87-103.

Wood CD, BN Tiwari, VE Plumb, CJ Powell, BR Roberts, VDP Sirimane, JT Rossiter and M Gill. 1994. Interspecies differences and variability with time of protein precipitation activity of extractable tannins, crude protein, ash, and dry matter content of leaves from 13 species of Nepalese fodder trees. J. Chem. Ecol. 20:3149-3162. 